\title{
EXCHANGE RATE REGIME, WORLD OIL PRICES, AND \\ THE MEXICAN ECONOMY
}

\author{
A Master's Thesis \\ by \\ MERVE ÇETINKAYA
}

\author{
Graduate Program in \\ Energy Economics, Policy and Security \\ İhsan Doğramac1 Bilkent University
}

Ankara

June 2020 

To my beloved father

Thank you for your support, inspiration, and patience, but most of all for your love 


\title{
EXCHANGE RATE REGIME, WORLD OIL PRICES, AND THE MEXICAN ECONOMY
}

The Graduate School of Economics and Social Sciences

$$
\text { of }
$$

İhsan Doğramacı Bilkent University

$$
\text { by }
$$

Merve Çetinkaya

\begin{abstract}
In Partial Fulfillment of the Requirements for the Degree of MASTER OF ARTS IN ENERGY ECONOMICS, POLICY AND SECURITY
\end{abstract}

Graduate Program in Energy Economics, Policy and Security

İhsan Doğramacı Bilkent University Ankara

June 2020 
I certify that I have read this thesis and have found that it is fully adequate, in scope and in quality, as a thesis for the degree of Master of Energy Economics, Policy and Security.

Supervisor: Prof. Dr. M. Hakan Berument

I certify that I have read this thesis and have found that it is fully adequate, in scope and in quality, as a thesis for the degree of Master of Energy Economics, Policy and Security.

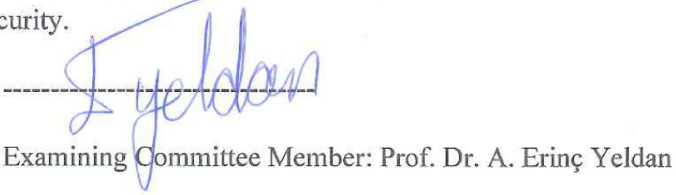

I certify that I have read this thesis and have found that it is fully adequate, in scope and in quality, as a thesis for the degree of Master of Energy Economics, Policy and Security.

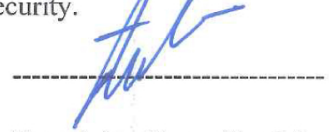

Examining Committee Member: Prof. Dr. Nükhet Doğan

Approval of the Graduate School of Economics and Social Sciences

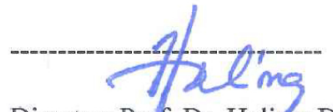

Director: Prof. Dr. Haline Demirkan 


\author{
ABSTRACT \\ EXCHANGE RATE REGIME, WORLD OIL PRICES, \\ AND \\ THE MEXICAN ECONOMY \\ Çetinkaya, Merve \\ M.A Program in Energy Economics, Policy and Security \\ Supervisor: Prof. Dr. M. Hakan Berument
}

June 2020

This thesis studies the effects of the exchange rate regime of the Mexican economy on how the oil price shocks affect the domestic economic performance by considering the period from January 1992 to December 2019. The empirical evidence reported here reveals that a positive oil price shock appreciates the local currency, increases the interest rate, output, and prices. Furthermore, once the exchange rate channel is closed, an increase in the interest rate and prices will be higher. However, we could not find statistically significant evidence that the effect on output does change with the exchange rate regime. This conclusion is parallel of a country that has a low level of inflation commitment.

Key Words: Exchange Rate Channel, Mexican Economy, Oil Price Shocks, Vector Autoregression Model 


\title{
ÖZET
}

\author{
DÖVIZZ KURU REJIMI, DÜNYA PETROL FIYATLARI \\ $\mathrm{VE}$ \\ MEKSIKA EKONOMISİ \\ Çetinkaya, Merve
}

Yüksek Lisans, Enerji Ekonomisi ve Enerji Güvenliği Politikaları Programı Tez Danışmanı: Prof. Dr. M. Hakan Berument

Haziran 2020

Bu tez, Ocak 1992'den Aralık 2019'a kadar olan dönemi göz önünde bulundurarak, Meksika döviz kuru rejiminin, petrol fiyatlarındaki şokların yerel ekonomik performansı nasıl etkilediğini incelemektedir. Çalışmada yer verilen ampirik araştırma sonuçları, pozitif petrol fiyat şokunun yerel para biriminin değerini ve üretimi arttırırken faiz oranları ile fiyatları da yükselttiğini göstermektedir. Bununla birlikte, döviz kuru kanalının kapatılmasıyla beraber faiz oranlarının ve fiyatların daha da arttığı gözlemlenmektedir. Ancak üretim üzerindeki etkinin döviz kuru rejimi ile orantılı olarak değiştiğine dair istatiksel olarak anlamlı herhangi bir bulguya rastlanmamıştır. Bu sonuç, düşük enflasyon taahhüdü olan bir ülkenin durumu ile paralellik göstermektedir.

Anahtar Kelimeler: Döviz Kuru Kanalı, Meksika Ekonomisi, Petrol Fiyat Şokları, Vektör Otoregresif Model 


\section{ACKNOWLEDGEMENTS}

I would like to express my special thanks of gratitude to my supervisor Prof. Dr.

Hakan Berument for his excellent guidance and support in completing my thesis.

I am very thankful to Levent Gül for his beneficial comments.

I would also like to extend my gratitude to Prof. Dr. Nükhet Doğan for her precious support. 


\section{TABLE OF CONTENTS}

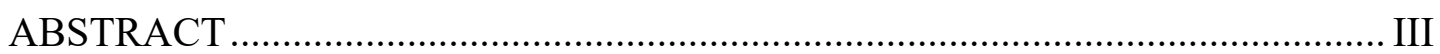

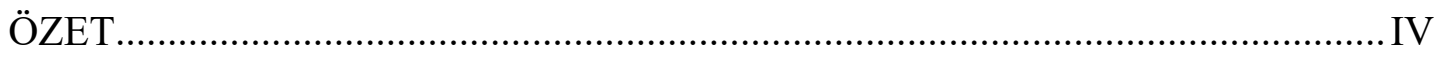

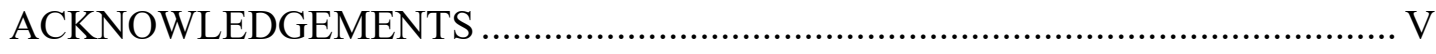

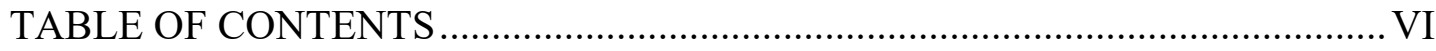

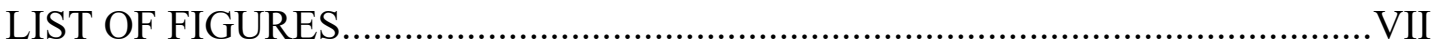

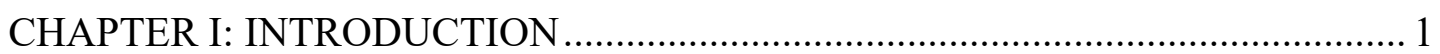

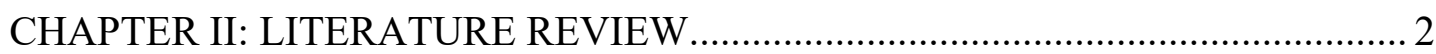

CHAPTER III: MEXICAN EXCHANGE RATE SYSTEM..................................... 8

CHAPTER IV: DATA AND METHODOLOGY ….................................................. 11

CHAPTER V: THE EFFECTS OF OIL PRICE SHOCKS ON THE MEXICAN

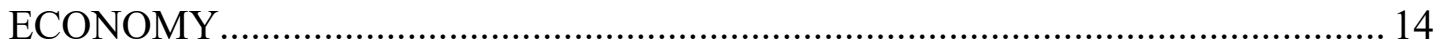

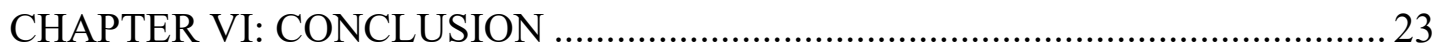

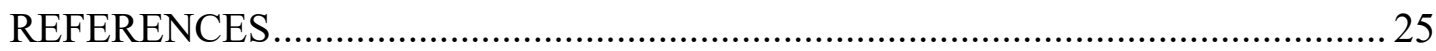




\section{LIST OF FIGURES}

1. THE MEXICAN EXCHANGE RATE FROM 1992 to 2019 9

2. IMPULSE RESPONSES TO WEST TEXAS INTERMEDIATE OIL PRICE SHOCKS FOR FULL SAMPLE: 1992-2019

3. IMPULSE RESPONSES TO BRENT OIL PRICE SHOCKS FOR FULL SAMPLE: 1992-2019

4. IMPULSE RESPONSES TO WEST TEXAS INTERMEDIATE OIL PRICE SHOCKS FOR FULL SAMPLE: 1992-2019 WITH REAL EXCHANGE RATE

5. IMPULSE RESPONSES TO BRENT OIL PRICE SHOCKS FOR FULL SAMPLE: 1992-2019 WITH REAL EXCHANGE RATE

6. IMPULSE RESPONSES TO WEST TEXAS INTERMEDIATE OIL PRICE SHOCKS FOR 2009-2019

7. IMPULSE RESPONSES TO BRENT OIL PRICE SHOCKS FOR FOR 2009-2019

8. IMPULSE RESPONSES TO WEST TEXAS INTERMEDIATE OIL PRICE SHOCKS FOR 2009-2019 WITH REAL EXCHANGE RATE

9. IMPULSE RESPONSES TO BRENT OIL PRICE SHOCKS FOR 2009-2019 WITH REAL EXCHANGE RATE 


\section{CHAPTER I}

\section{INTRODUCTION}

Oil is one of the most important commodities to be traded, and its prices affect external balance of almost all the countries as well as their domestic economic performances. The purpose of this thesis is to assess how the exchange rate regime can be used to control the effect of oil price shocks on a domestic economy for one of an important oil-exporting country: Mexico. The empirical evidence reported here suggests that the exchange rate mechanism might be used to decrease the effects of oil price shocks to domestic economy.

The effects of the oil prices are crucial for all the countries both oil-importing and oil-exporting ones. The Mexican economy is one of the oil-exporting countries that is affected by oil prices (García, Saucedo, \& Velasco, 2018). In this thesis, the Mexican economy is analyzed since it is one of the prominent countries that is noted as an oil-exporting country and has maintained a floating exchange rate regime successfully for a relatively long period of time. Besides exporting oil, refined products are one of the most important goods it imports. To illustrate, in 2017, Mexico exported $\$ 418$ billion, $\$ 19.5$ billion of which was crude petroleum whereas it imported \$356 billion, \$23.4 billion of which was refined products (Simoes \& Hidalgo, 2011). 


\section{CHAPTER II}

\section{LITERATURE REVIEW}

One of the first variables affected by the oil prices through current account balance is the exchange rate through terms of trade. Garcia, Saucedo, and Velasco (2018) find that an increase/decrease in the oil spot price appreciates/depreciates the domestic currency against the U.S dollar. Lizardo and Mollick (2010), by using a VAR model for major oil-exporting and oil-importing countries with two variables - oil prices and the exchange rate- show that an increase in real oil prices lead to a significant appreciation of net oil exporters' currencies such as the Mexican peso. By using a GARCH-M framework for five major oil-exporting countries with two variables -oil prices and the exchange rate- Volkov and Yuhn (2016) find that the volatility of exchange rates associated with oil price shocks is significant in Mexico and an increase in oil prices lead to a significant appreciation of the domestic currency of Mexico. Mohommadi and Jahan-Parvar (2010), by using TAR and M-TAR model for thirteen oil-exporting countries with two variables- oil prices and the real exchange rate-, find that high oil prices make contribution to the real exchange rate appreciation in the long-run. Another related study conducted by Jahan-Parvar and Mohommadi (2008) exhibits the existence of a stable long-run relation between real oil prices and real exchange rates, implying that an increase in oil prices leads to real 
exchange rate appreciation. As a result of these studies, it is worth noting to mention about the exchange rate channel in the transmission mechanism. Oil price shocks have a stimulating effect on the Mexican economy, appreciate the Mexican peso, which makes domestic good relatively expensive than foreign goods, hence, improve the terms of trade, bring down the inflation either through lower import prices or a wage index mechanism.

For the effects of oil prices on the Mexican consumer price index (CPI) Delgado, Delgado and Saucedo (2018) cannot find statistically significant effect created by an increase in the oil prices on the consumer price index. They explain the effects of the consumer price index by using the exchange rate channel. According to their studies, the appreciation of the Mexican peso leads to a decrease in the Mexican consumer price index. Jacyk (1998); Sek, Teo and Wong (2015); Lescaroux and Mignon (2008) observe that the positive oil price shocks have a positive effect on both CPI and industrial production. They argue that higher oil prices can transmit into inflation through supply channel. Higher oil price leads to inflationary pressure and creates a higher price of final goods. Higher oil price also transmit by means of cost channel where higher oil prices prompt higher cost of production. Choi, Furceri, Loungani, Mishra and Poplawski-Ribeiro (2018) find that a \%10 raise in global oil prices increases in domestic inflation by about $\% 0.4$ points on impacts.

Various studies have observed the effects of oil prices on output as well. The effects of oil prices on economic performance for oil-exporting countries has been studied. Berument, Ceylan and Dogan (2010) study the effects of oil price shocks on the output growth of selected Middle East and North African (MENA) countries that are either oil-exporters or oil-importers. Their studies suggest that the effects of world 
oil prices on GDP in most of oil exporters and oil importers are positive and statistically significant. Jimenez-Rodrgíuez and Sánchez (2005) analyze its effect on real economic performance for Norway and the UK and find that oil price shocks negatively affect UK output but positively affect the Norwegian output. Aleisa and Dibooglu (2002) state that oil production shocks in the Saudi Arabia have a major effect on output by way of real exchange rate movement. For instance, Mehrara and Mohaghegh (2011); Guerrero, Valle and Vega (2018) find that the effect of world oil price on GDP in oil-exporting countries is positive and statistically significant, implying that the source of oil shock is a raise in global demand, GDP increases for most countries in their sample. For oil- exporting countries, oil price shocks affect GDP growth through direct output and inflationary channels. The direct output channel is where GDP directly increases because of higher oil income; the inflationary channel is which affects GDP through consumer price index, inflation, investment and foreign indirect investment (Skakun, 2019, p. 167). According to Grigoli, Herman and Swiston (2017), a decline in oil prices between 2014 and 2016 caused a large deviation of real GDP growth of Mexico as an oil-exporting country.

The efficient use of revenue from energy resources can be a motive of economic growth, wealth and stability for a country. However, the volatility and uncertainty of this income can be a challenge for the economic development of a country. For oilexporting countries like Mexico, where oil revenues represent a significant portion of total government revenue, a sudden change in oil prices jeopardize the fiscal balances of the government and destabilize the economy. OECD Economics Surveys (2009) indicate that such oil producing countries as Mexico have found it difficult to facilitate government expenditure over time and decouple it from the volatility of oil prices leading to boom-bust cycles. In 2008, when the worst financial crisis in 
decades, West Texas Intermediate (WTI) oil prices plunge down from the peak levels above $\$ 140$ per barrel to about $\$ 40$ in less than six months (Duclaud \& Garcia, 2012, p. 297). In addition, IMF Article IV Consultation (2007) points out that the pace of Central Bank of Mexico's passive reserve accumulation can be affected by fluctuations in oil prices; this may dampen the sensitivity of the Mexican peso to such price volatility. Fluctuation in oil prices results in output volatility that weaken the Mexican economy as other oil-exporting economies. To reduce the vulnerability occurred by oil dependence, the Mexican government has carried out various oilhedging programs and established an Oil Income Stabilization Fund (FEIP) in 2000.

To eliminate the adverse effect of oil price shocks on output, this thesis studies controlling the exchange rate as a policy tool. The exchange rate is an essential policy variable and has implications for the economic performance of an oil exporting economy like Mexico. The interaction of exchange rate with oil prices reveals comprehensive understandings to the central bank for managing currency rates to maximize economic growth and keep inflation under the desired level. There are several studies that analyze the effects of the exchange rate on output and prices. By using a VAR model for Mexico with four variables -money growth, output, government expenditures and inflation, Rogers and Wang (1995) conclude that the effect of devaluation to output is negative and monetary shocks are allowed to affect output with a lag, as it is consistent with the conventional point of the monetary transmission mechanism. On the other hand, Copelman and Werner (1995), by using a VAR model with five variables- the real exchange rate, rate of depreciation of the nominal exchange rate, output, the real interest rate and a measure for real money balance- try to address how the transmission mechanism of monetary policy works. They demonstrate that the decrease in output is observed after a devaluation. They 
find that the credit view of the monetary transmission mechanism is relevant for the case of Mexico. The shocks to credit are mostly due to changes in nominal depreciation rate and these shocks to depreciation rate have the negative effect on the output through credit channel. Furthermore, a shock to the volume of credits causes a real exchange rate appreciation as aggregate demand raises increasing the prices. Kamin and Rogers (2000) find empirical evidence that the effect of real devaluation has led to high inflation and low output in the Mexican economy while it leads to a sustained reduction in the real GDP. Their impulse response functions indicate that an increase in the interest rate generally decreases output, while increases in oil prices, the capital account, government spending, and real M2 tend to increase real GDP.

In order to assess the effects of oil price shocks, we employ a Vector Autoregression model as modified by Bernanke, Gertler and Watson (1997) with the monthly data for the period of January 1992 to December 2019. This model enables us to assess the direct and indirect effects of oil price shocks on the Mexican economy by modifying policy driven exchange rate under three different specifications. The first one called as the base scenario, is the standard VAR model, which allows oil prices to freely affect the exchange rate without any restriction. The Alternative Scenario I is the one where the exchange rate channel is closed, and it does not respond to any macroeconomic variables. The Alternative Scenario II is the scenario where the direct effect of the oil price shock is restricted on the exchange rate, though, indirect effects exists via other variables are allowed.

In the next part of the thesis, the Mexican exchange rate system is summarized by highlighting the historical turning point of the system. In the fourth section, the 
methodology and data used in the study are introduced. In the fifth section, the effects of oil price shocks on the macroeconomic variables are examined in detail. The conclusion part of the paper involves a general evaluation about the study. 


\section{CHAPTER III}

\section{MEXICAN EXCHANGE RATE SYSTEM}

The central bank of Mexico (Banco de Mexico) with credibility problems had utilized the fixed exchange rate regime as an anchor since 1987 to stabilize its inflation. Although successful results had been attained in the implementation of the fixed exchange rate regime in combating inflation, Mexico had a set of difficulties in applying this exchange rate regime (Carstens \& Werner, 1999, p. 5). In 1994, the Mexican current account deficit had increased to about 29 billion USD, Mexico's international reserves declined about two-thirds, and the government of Mexico issued more than 25 billion USD of peso-denominated short run debt whose nominal value was indexed to the U.S dollar (Truman,1996, p. 199). The economic difficulties that Mexican economy had experienced led to the collapse of the fixed exchange rate system and in December 1994 the Foreign Exchange Commission integrated by Central Bank of Mexico and the Ministry of Finance- decided to allow the Mexican peso float (Cano, Gallardo, \& Acosta, 2019, p. 196). 


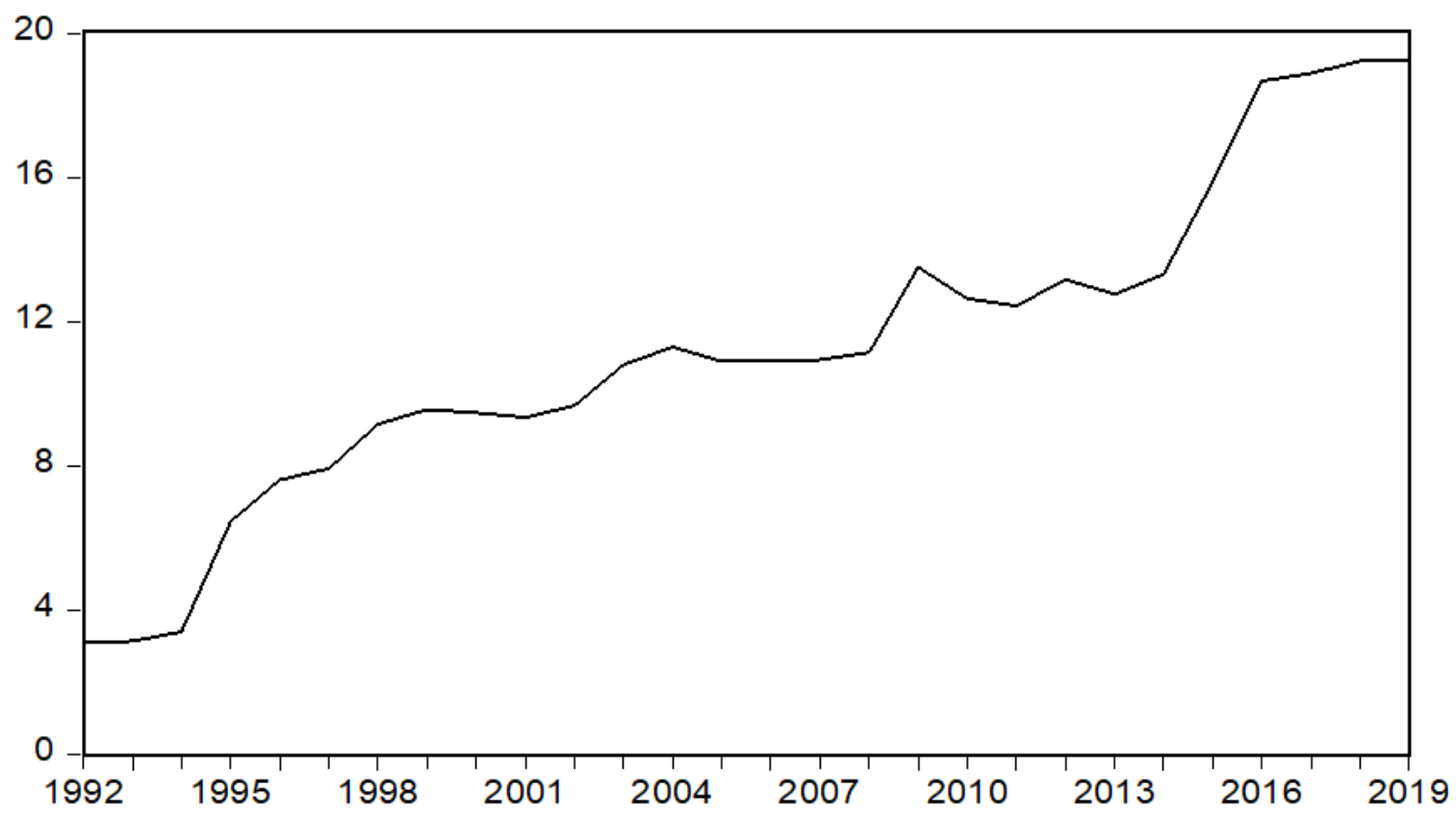

Figure 1: Mexican Exchange Rate from 1992 to 2019

Source: St. Louis Fed: FRED

Figure 1 plots the evolution of the Mexican peso/ U.S dollar parity. The exchange rate has followed three patterns since it began to float. One of them is a sharp depreciation and volatility in the aftermath of the crisis in 1994. Depending upon the uncertainty after the crisis, there was a significant depreciation in the Mexican peso. However, with the announcement of the IMF program and international aid support in April 1995 the movement of the exchange rate followed a more stable course. The domestic currency that moved calmly until 1998 had suffered a depreciation due to the Russian crisis and devaluation that occurred in December. Second path is a mild appreciation and stability up to 2008 (Sidaoui, 2005, p.202). With the effects of global financial crisis in 2008, Mexican peso severely depreciated against the U.S dollar. Lastly, the losing value of the Mexican peso began afresh in the late 2014 with the decrease in the oil prices. Along with the reduction in oil prices, an increase in the U.S. interest rate have made Mexico comparatively less attractive to make investment. Besides these economic fluctuations, in 2016, tensions caused by the 
presidential election in the United States accelerated the depreciation of the Mexican peso. 


\section{CHAPTER IV}

\section{DATA AND METHODOLOGY}

In order to assess the effects of oil prices on the Mexican economic performance, following Bernanke, Gertler and Watson (1997), a set of VAR models are estimated by using the monthly data from January 1992 to December 2019. In our data, we use WTI for crude oil prices, the currency exchange rate of Mexican pesos per U.S dollar as the exchange rate, Mexican interbank interest rate for interest rate, industrial production for output and consumer price index for prices. Data for oil prices are attained from the World Bank. Data for the exchange rate (peso/dollar) and consumer price index are from Banco de Mexico. Data for industrial production and interest rate are acquired from Federal Reserve Bank of St. Louis. All these variables enter the system in logarithms except for interest rate.

In this section, first we introduce the benchmark VAR model that we use to estimate the effects of oil prices on Mexican economy as an unconstraint vector autoregression (VAR) model. The model allows the exchange rate to be interactive with the rest of variables without any parameter constraint. The benchmark VAR specification comprises variables as a measure of oil prices, exchange rate, interest rate, industrial production, and consumer price index. We use a lag order of five, as suggested by the Akaike Information Criteria (AIC). Next, we assess the effects of the oil prices are gathered by controlling the exchange rate in two different scenarios. 
In order to identify oil shocks, we employ the Cholesky decomposition in our model; hence, the order of variables is important. All variable orders are influenced by the preceding variables simultaneously but are not influenced by the latter variables simultaneously. However, all variables influence each other with a lag. The variables are ordered as oil prices (OP), exchange rate (ER), interest rate (R), industrial production (IP) and consumer price index (CPI). Thus, oil prices influence exchange rate, interest rate, industrial production, and consumer price index simultaneously but are not affected by these variables simultaneously. Similarly, exchange rate is affected by oil prices simultaneously and affects subsequent variables simultaneously. Yet, again, all of these variables influence each other with a lag.

Taking into account of Mexico's position on oil industry, this ordering suggests that the oil prices affect the Mexican economy simultaneously but not vice versa. In alternative two scenarios, the Alternative Scenario I assumes that the exchange rate is unresponsive to all the economic variables. The Alternative Scenario II assumes that the exchange rate responds to all the variables but not the oil prices itself. The base unconstraint VAR model with the Cholesky decomposition used for the base scenario can be written as below

$$
\begin{aligned}
& O P_{t}=\sum_{i=1}^{p}\left(\pi_{O P, O P . i} O P_{t-i}+\pi_{O P, E R . i} E R_{t-i}+\pi_{O P, R . i} R_{t-i}+\pi_{O P, I P . i} I P_{t-i}+\pi_{O P, C P I . i} C P I_{t-i}\right) \\
& +\varepsilon_{O P . t} \\
& E R_{t}=\sum_{i=1}^{p}\left(\pi_{E R, O P . i} O P_{t-i}+\pi_{E R, E R . i} E R_{t-i}+\pi_{E R, R . i} R_{t-i}+\pi_{E R, I P . i} I P_{t-i}+\pi_{E R, C P I . i} C P I_{t-i}\right) \\
& +\gamma_{E R, O P . i} \varepsilon_{O P . t}+\varepsilon_{E R . t} \\
& R_{t}=\sum_{i=1}^{p}\left(\pi_{R, O P . i} O P_{t-i}+\pi_{R, E R . i} E R_{t-i}+\pi_{R, R . i} R_{t-i}+\pi_{R, I P . i} I P_{t-i}+\pi_{R, C P I . i} C P I_{t-i}\right) \\
& +\gamma_{R, O P . i} \varepsilon_{O P . t}+\gamma_{R, E R . i} \varepsilon_{E R . t}+\varepsilon_{R . t}
\end{aligned}
$$




$$
\begin{aligned}
& I P_{t}=\sum_{i=I}^{p}\left(\pi_{I P, O P . i} O P_{t-i}+\pi_{I P, E R . i} E R_{t-i}+\right.\left.\pi_{I P, R . i} R_{t-i}+\pi_{I P, I P . i} I P_{t-i}+\pi_{I P, C P I . i} C P I_{t-i}\right) \\
&+\gamma_{I P, O P . i} \varepsilon_{O P . t}+\gamma_{I P, E R . i} \varepsilon_{E R . t}+\gamma_{I P, R . i} \varepsilon_{R . t}+\varepsilon_{I P . t} \\
& C P I_{t}=\sum_{i=I}^{p}\left(\pi_{C P I, O P . i} O P_{t-i}+\pi_{C P I, E R . i} E R_{t-i}+\pi_{C P I, R . i} R_{t-i}+\pi_{C P I, I P . i} I P_{t-i}+\pi_{C P I, C P I . i} C P I_{t-i}\right) \\
&+\gamma_{C P I, O P . i} \varepsilon_{O P . t}+\gamma_{C P I, E R . i} \varepsilon_{E R . t}+\gamma_{C P I, R . i} \varepsilon_{R . t}+\gamma_{C P I, I P . i} \varepsilon_{I P . t}+\varepsilon_{C P I, C P I . t}
\end{aligned}
$$

The Alternative Scenario I is that the exchange rate does not respond to any macroeconomic variable that we set up. Hence, we can evaluate how the exchange rate influences economic development if policy makers can keep exchange rate constant. In other words, in equation (2), zero constraints are imposed for $\pi_{E R, O P . i}$, $\pi_{E R, R, i}, \pi_{E R, I P . i}, \pi_{E R, C P I . i}, \gamma_{E R, O P . i}$ for all $i$ so as to shut the exchange rate toward both direct and indirect effects. The Alternative Scenario II is that exchange rate responds all variables except for oil price shocks. Oil price shocks affect exchange rate indirectly. In order to shut oil price effects in the model, zero constraints are applied for $\pi_{E R, O P . i}$ and $\gamma_{E R, O P . i}$ for all $i$. 


\section{CHAPTER V}

\section{THE EFFECTS OF OIL PRICE SHOCKS ON THE MEXICAN ECONOMY}

Figure 2 reports the impulse response functions when one standard deviation shock is given to oil prices for three different scenarios that we consider. We report the confidence one-standard-error bands for the base scenario and the impulse responses without the confidence bands for the alternative scenarios. ${ }^{1}$ The solid black lines report the lower and upper bounds of the confidence interval of the base scenario. The dashed line represents the impulse response when exchange rate is constant (Alternative Scenario I). The dotted line reports the impulse response when exchange rate responds all variables except for oil price shocks (Alternative Scenario II). Panel A of Figure 2 demonstrates how one standard deviation shock to WTI oil price affects itself for 24 periods. Under the base scenario, it is seen that the effect is statistically significant during all periods. When response of the oil prices to itself is compared with two scenarios, oil prices under the two alternative scenarios follow the same course as seen in panel $\mathrm{A}$, and the medians of the alternative scenarios are lower than the median of the base scenario during periods under review. Thus, the estimates suggest that the restrictions in the exchange rate indicate that the oil prices

\footnotetext{
${ }^{1}$ In order to avoid multiple lines in the figure, which could be confusing, we only report the confidence one-standard-error bands for the base scenario. If required, it can be requested from the author.
} 
increase less and the effect of the shock dissolves earlier. However, there is no statistically significant difference compared to base scenario.

Panel B of Figure 2 reports the impulse responses on how the exchange rate responds to an oil price shock. It is observed that the exchange rate decreases and this effect is statistically significant throughout 24 periods that we consider as a result of one standard deviation shock given to WTI oil prices. With the decrease in the exchange rate, the value of domestic currency -Mexican Peso- is increasing and this trend has increased rapidly in the first four periods, but it has been slowing down after the fifth period. There is no exchange rate response since the exchange rate will remain in the pre-shock period and will not respond to other variables in the Alternative Scenario I. In the Alternative Scenario II, for the first two periods the exchange rate is increasing, and the domestic currency depreciates. During first nine period, there is a statistically significant difference since the impulse response goes out of the confidence interval. It is interpreted that exchange rate decreases; thus, Mexican peso starts to appreciate. However, it is worthwhile to underline that the decrease in the exchange rate is lower than the base scenario.

Panel $\mathrm{C}$ of Figure 2 reports the impulse responses of the interbank interest rate. The effect is statistically significant during first four periods. The impulse responses for the interest rate from the Alternative Scenario I suggest that the interest rate moves with the base scenario until the third period. In the Alternative Scenario I, there is a statistically significant difference from the base scenario between fourth and tenth period on the interest rate. The median of both alternative scenarios is higher than the median of the base scenario. Furthermore, it is seen that when given to one standard 
deviation shock to WTI oil prices, interest rate increases further under the Alternative Scenario I compared to the base scenario.

Panel D of Figure 2 reports the impulse responses for the industrial production. The confidence bands under the base scenario illustrate that the effect is positive and statistically significant between the second period and twelfth period. The responses of industrial production in the alternative scenarios are almost the same as seen in Panel D. The medians of alternative scenarios are lower than the median of the base scenario when the positive effect is accelerating. However, in the following periods, it takes the same course as the base scenario and no significant difference is observed. Consequently, keeping the exchange rate constant or restricting the direct impact of the oil price does not make a statistically significant difference to industrial production compared to what the base scenario suggests. Moreover, it is seen that the increase in industrial production is lower under two alternative scenarios.

Panel E of Figure 2 reports the impulse response for consumer prices. Under the base scenario, confidence bands illustrate that the impulse response of CPI is not statistically significant, however, under the both alternative scenarios consumer prices are always higher than the median of consumer prices under the base scenario. Thus, when the exchange rate is kept constant or oil prices affect indirectly, prices increase more. In addition, there is a statistically significant difference between the base scenario and the Alternative Scenario I after the secondary period. The statistically significant difference between the base scenario and the Alternative Scenario II is observed between the third and ninth period.

Next, we provide a set of further analyses to evaluate the robustness of the results obtained from Figure 2 under different set-ups. We repeat the analysis for a one 
standard deviation oil price shock and we employ Brent oil prices instead of WTI as the oil prices. The results are reported in Figure 3, which demonstrate that the main inferences from Figure 2 are robust. The impulse responses of the exchange rate illustrate that whereas the difference between the base scenario and the Alternative Scenario II is statistically significant during first ninth period in the Figure 2, this difference is statistically significant for the first fifth period in the Figure 3. Moreover, it is noticed that when Brent oil prices are used, CPI increases less than the one use WTI oil prices.

To provide an additional robustness of our analysis, we use WTI for crude oil prices with the real exchange rate instead of the nominal exchange rate. Figure 4 reports the corresponding impulse responses, and illustrates that the results from Figure 2 are robust. In Figure 5, we employ Brent for crude oil prices with the real exchange rate in order to ensure that our analysis is robust. When two figures are compared, it can be seen that impulse responses demonstrate almost the same outcomes.

In Figure 6-7-8-9, unlike the previous ones, we employ a sub-sample between January 2009 and December 2019 rather than full sample. We pick data from 2009 in order to exclude the effects of the global financial crisis that led to oil prices to set a record higher than ever. It is possible to state that although there is no difference between the impulse responses created with full samples and the impulse responses created with sub-samples overall, there is an initially positive effect on real exchange rate when the sub-sample is used.

Briefly, we consider various alternatives for the relative effect of oil price shocks on the macroeconomic variables when the exchange rate is controlled and restrictions of 
direct effect of oil prices on the exchange rate, and we find that the estimates for the interest rate, industrial production and CPI are robust. 


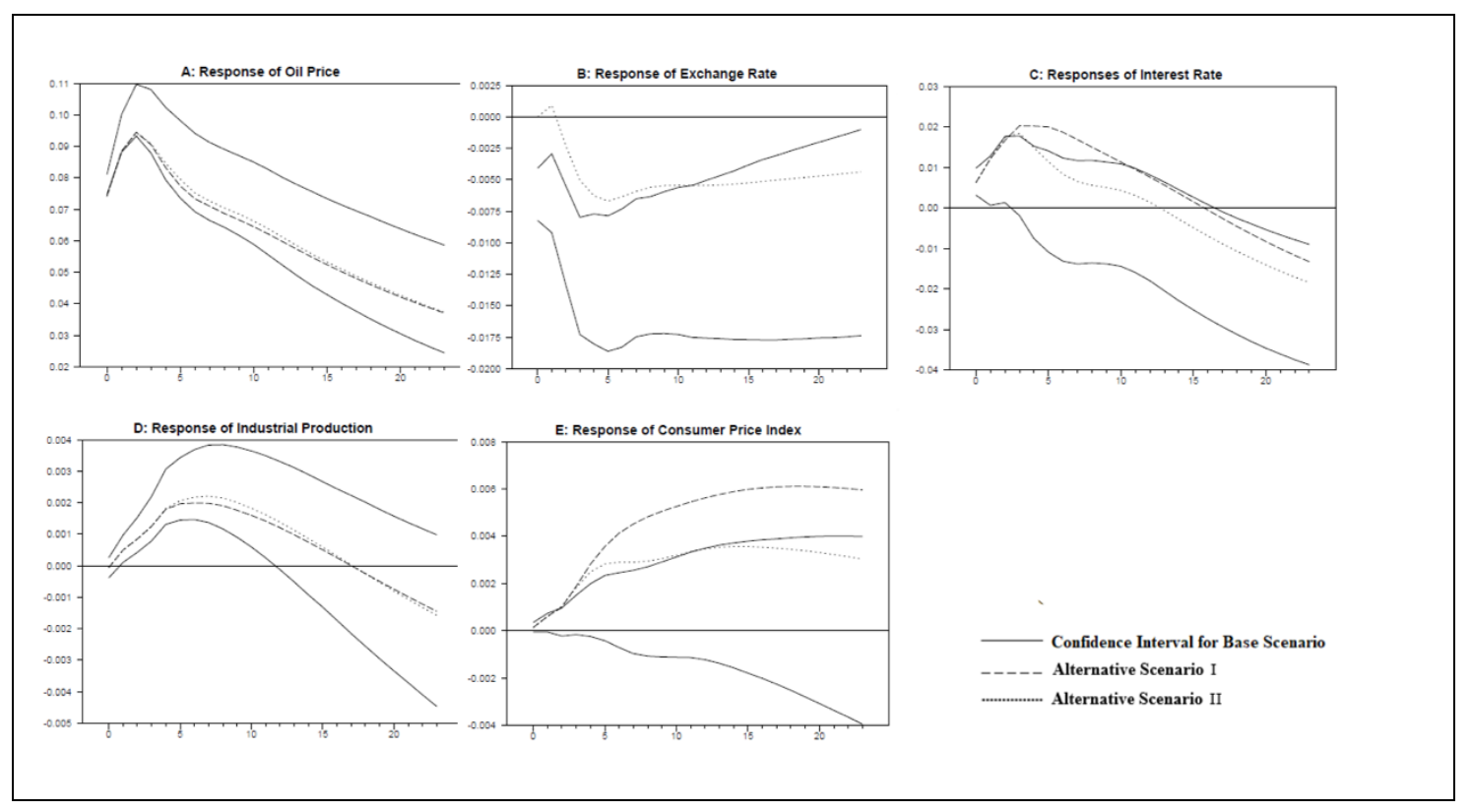

Figure 2: Impulse Responses to West Texas Intermediate Oil Price Shocks for Full Sample: 1992-2019

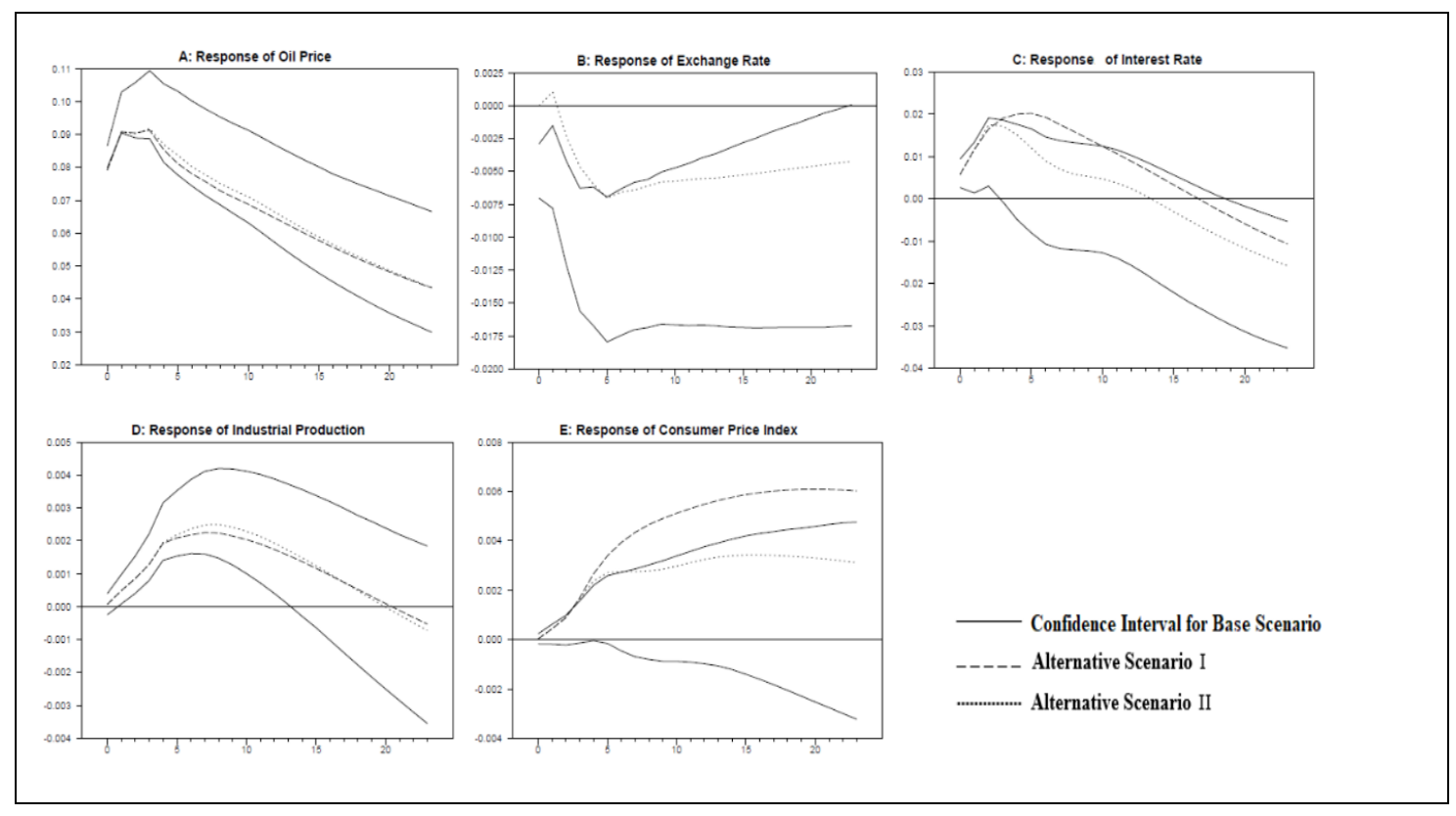

Figure 3: Impulse Responses to Brent Oil Price Shocks for Full Sample: 1992-2019 


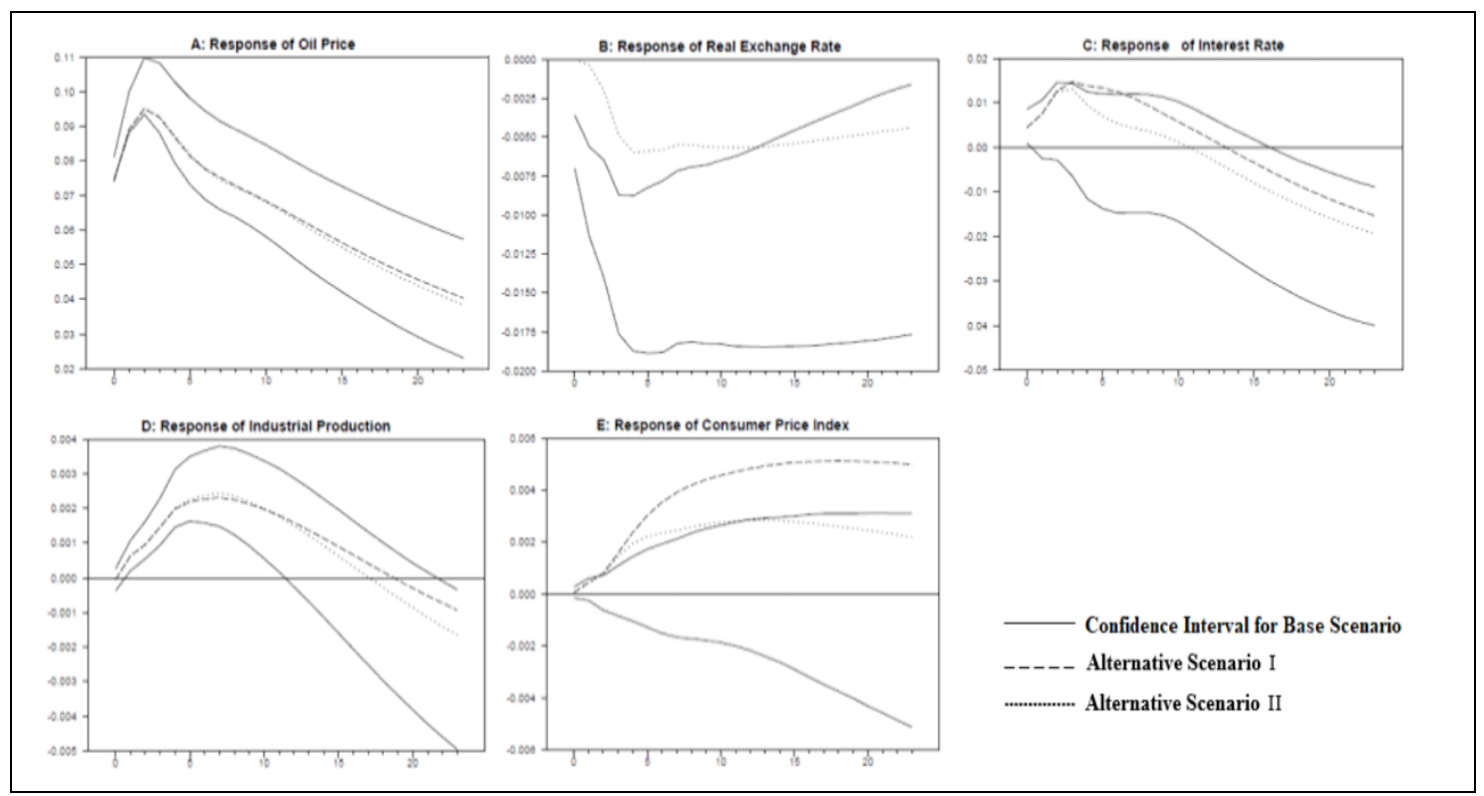

Figure 4: Impulse Responses to West Texas Intermediate Oil Price Shocks for Full Sample: 1992-2019 with the Real Exchange Rate

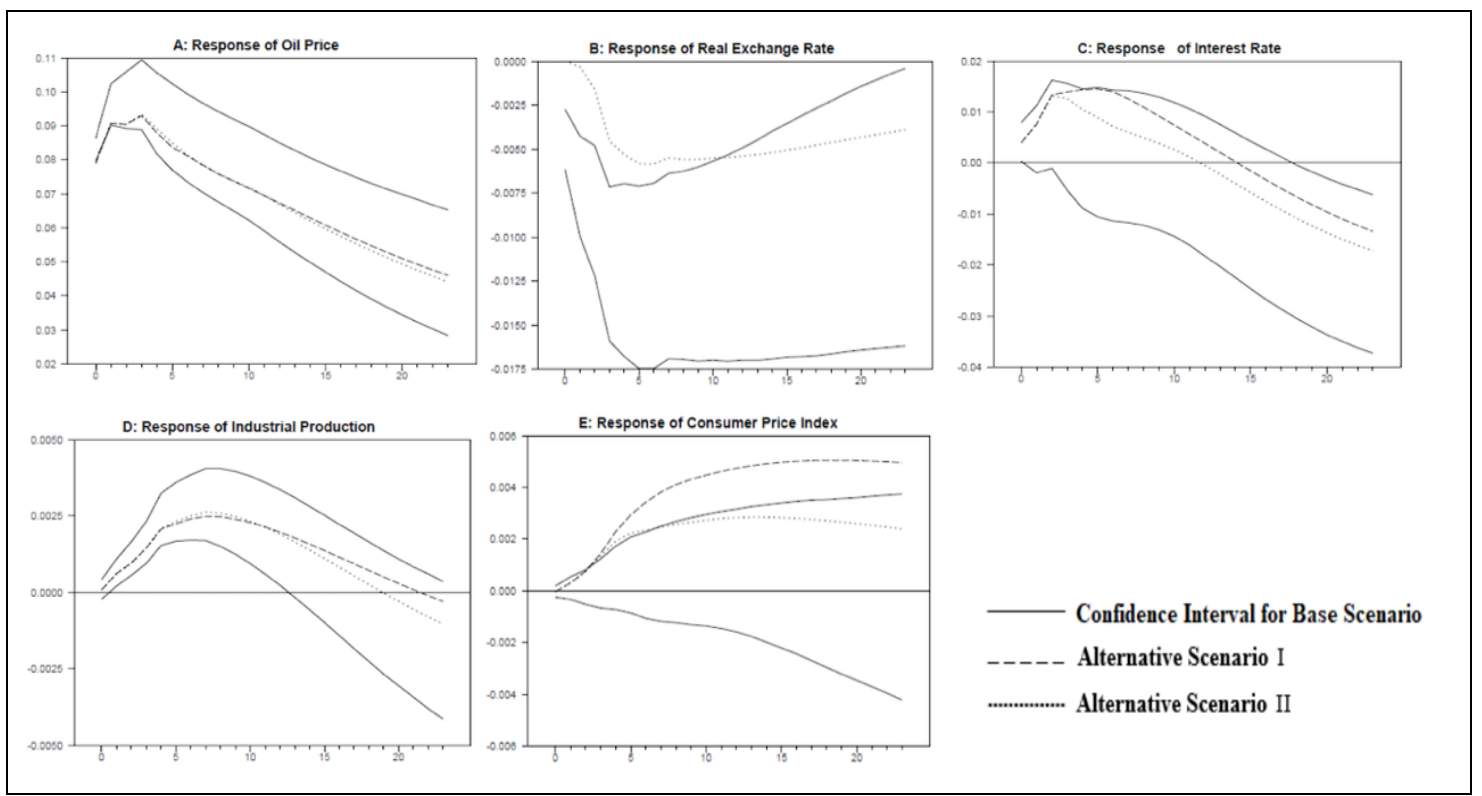

Figure 5: Impulse Responses to Brent Oil Price Shocks for Full Sample: 1992-2019 with the Real Exchange Rate 


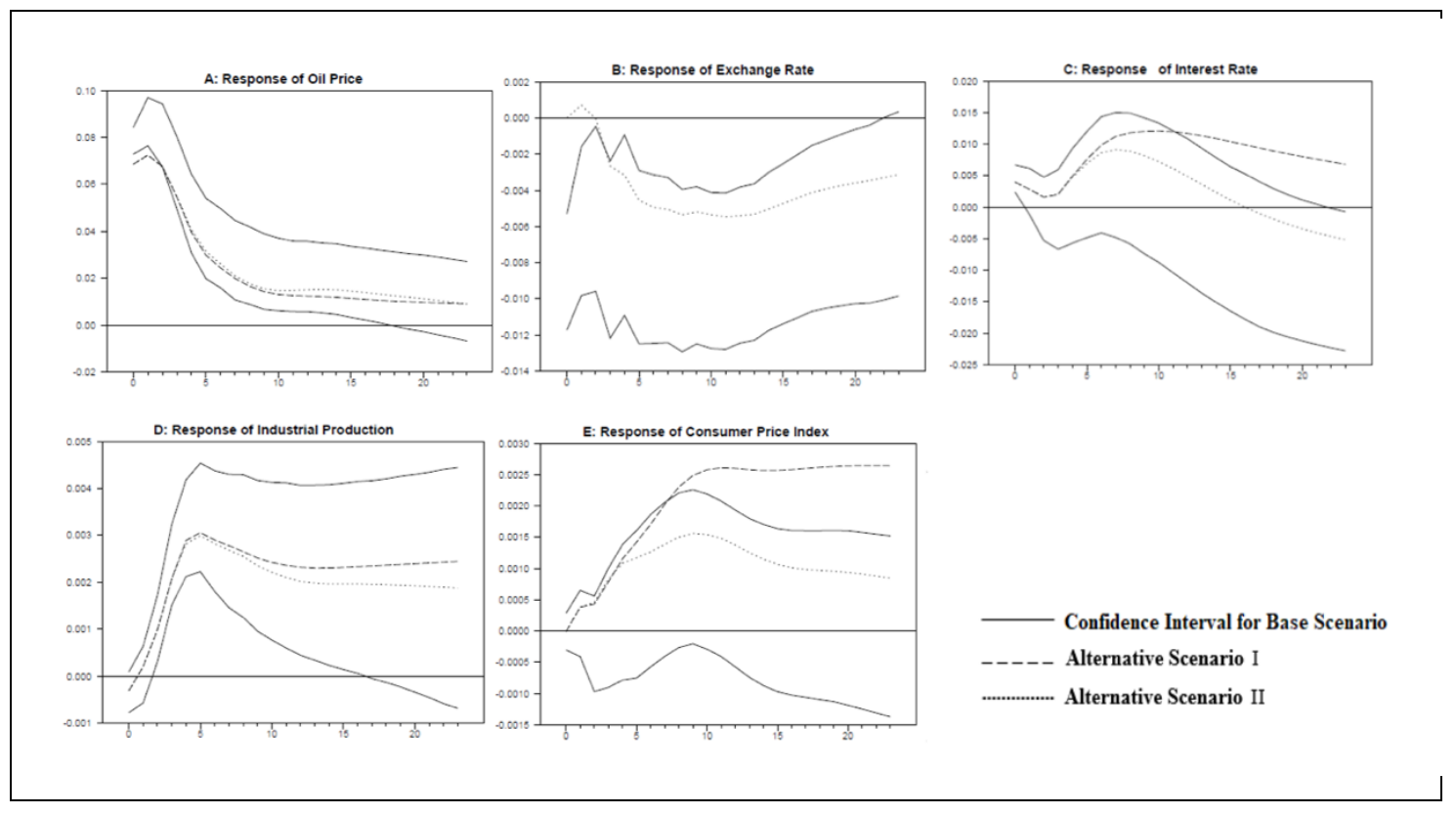

Figure 6: Impulse Responses to West Texas Intermediate Oil Price Shocks for 20092019

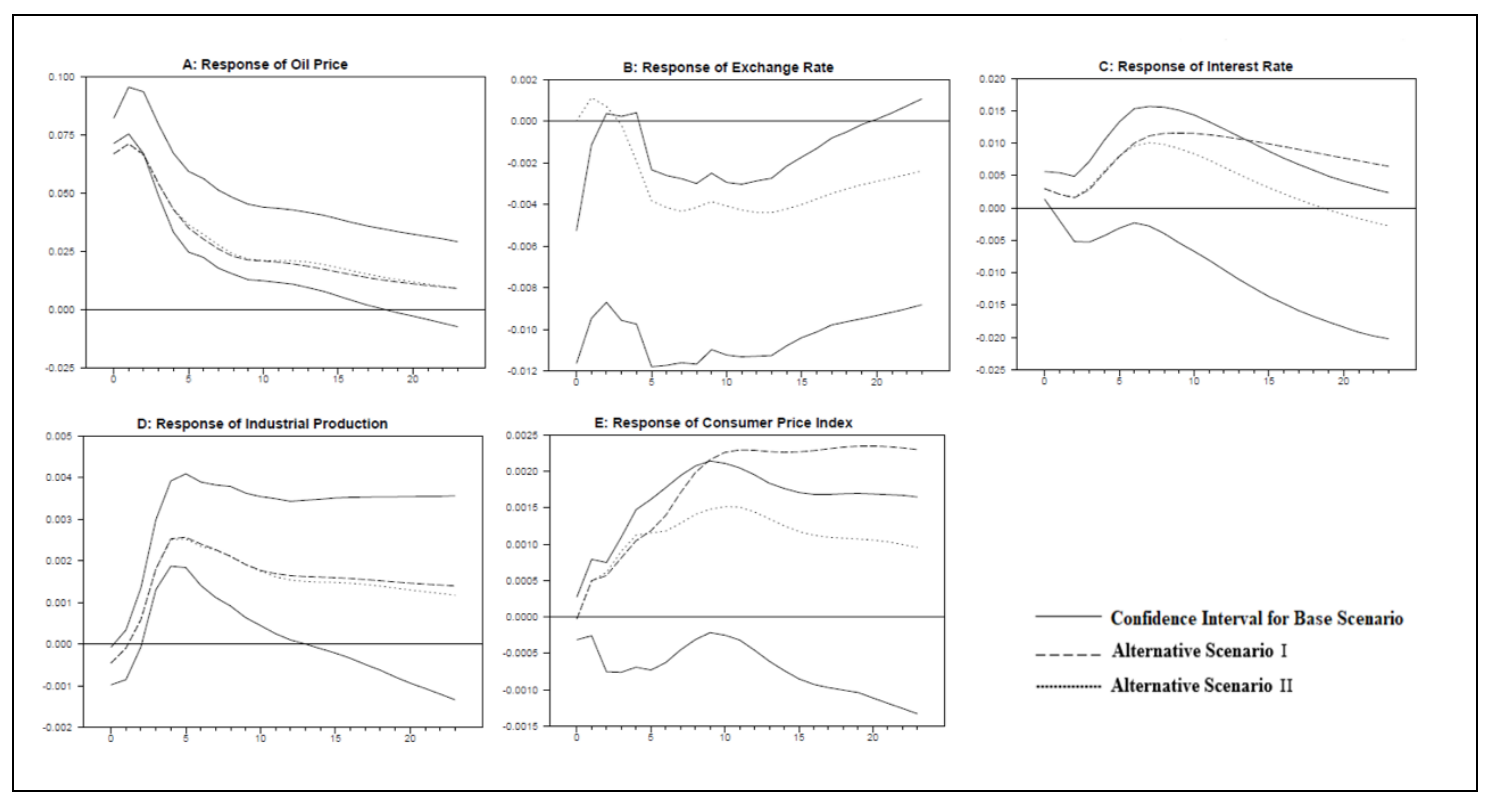

Figure 7: Impulse Responses to Brent Oil Price Shocks for 2009-2019 


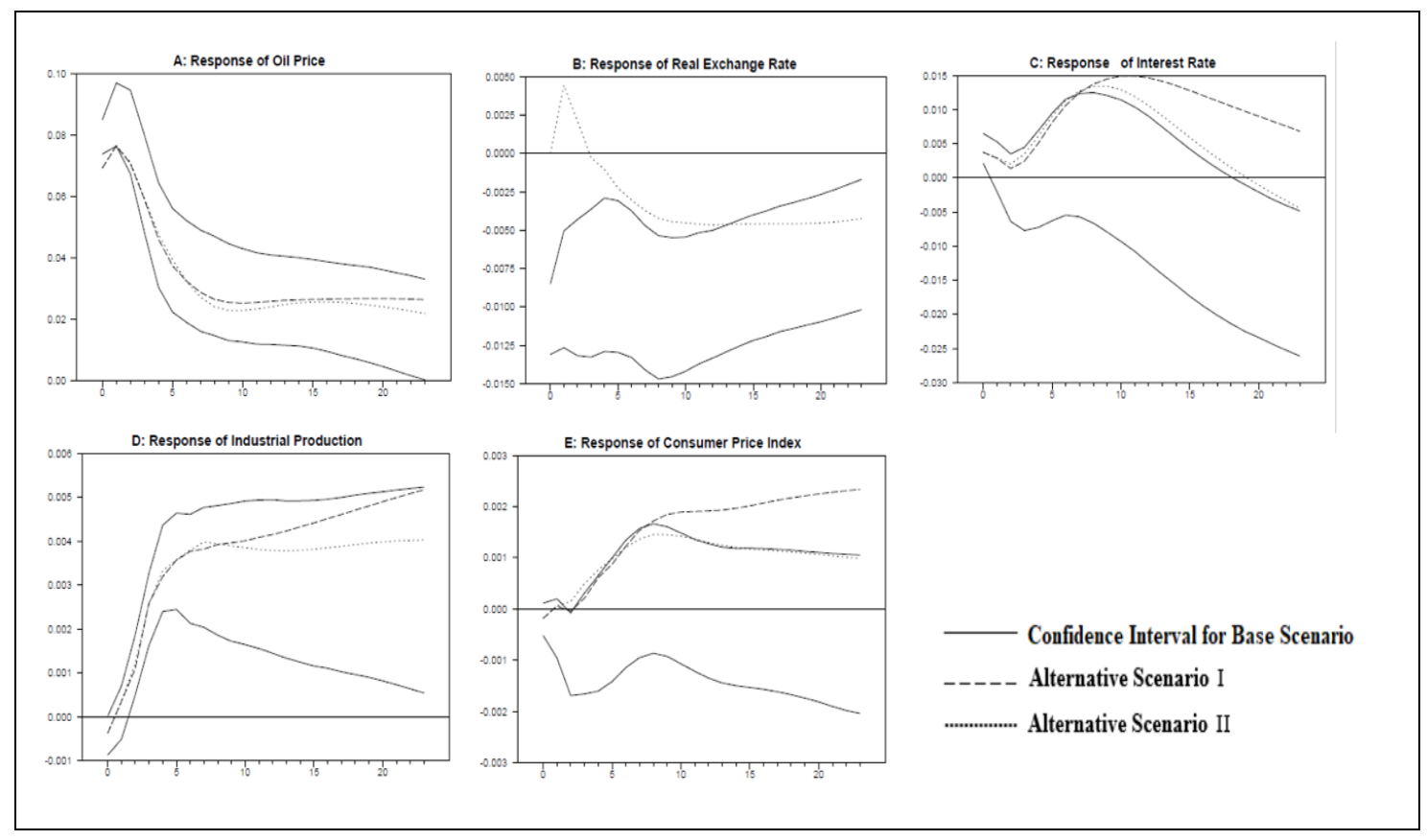

Figure 8: Impulse Responses to West Texas Intermediate Oil Price Shocks for 20092019 with the Real Exchange Rate

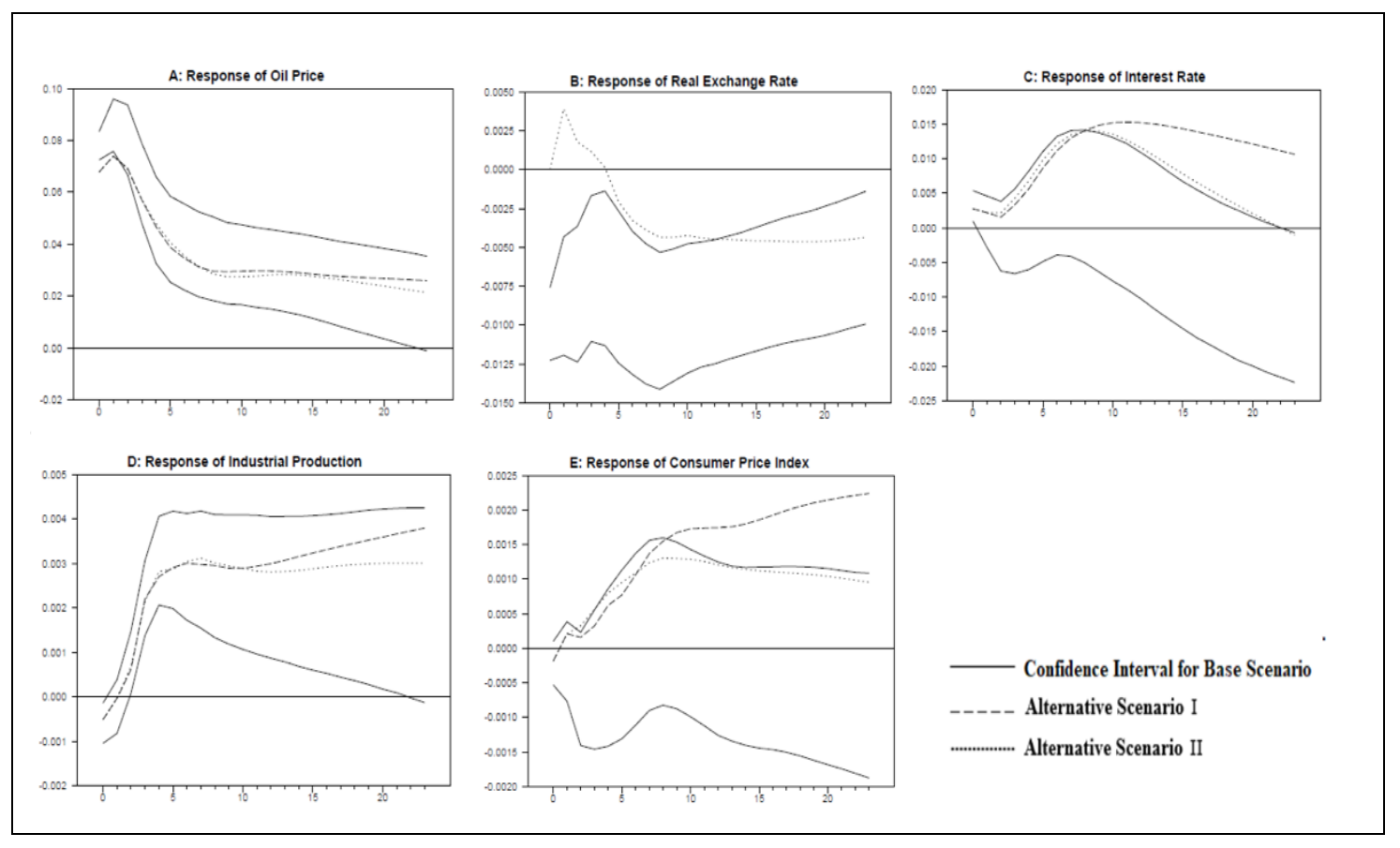

Figure 9: Impulse Responses to Brent Oil Price Shocks for 2009-2019 with the Real Exchange Rate 


\section{CHAPTER VI}

\section{CONCLUSION}

This thesis assesses the effect of exchange rate policy on the Mexican economy when the oil price shocks transmit to domestic economy. We used Bernanke, Gertler and Watson's (1997) VAR specifications in order to analyze these effects under three different scenarios. The first scenario called as the base scenario, is the standard VAR model, which allows oil prices to freely affect the exchange rate without any restriction. The Alternative Scenario I that the exchange rate channel is shut down is the scenario where the exchange rate remains before the pre-shock level and does not respond to any macroeconomic variables. The Alternative Scenario II is the scenario where the direct effect of the oil price shock is not observed on the exchange rate, however, an indirect effect exists through other variables in the system.

Findings of our study indicate that oil price appreciates the local currency in a statistically significant fashion. A one standard deviation shock is given to oil prices leads to an increase in the interest rate, industrial production and CPI. When we compare to the alternative scenarios with the base scenario, the Mexican peso appreciates significantly less, the interest rate increases more, the increase in the overall price level is higher, and the increase in industrial production is less. Moreover, these results are robust to alternative specifications. These findings suggest that constraining exchange rate may help the economy to decrease the 
adverse effects of the oil price shocks. Along with, even though shutting down the exchange rate channel further increases interest rate, it may lead to a higher increase in prices than what the base scenario suggests. These results suggest that controlling the exchange rate may be a helpful macroprudential policy tool to improve economic performance. However, a higher appreciation of domestic currency may bring about the vulnerability of domestic economy. In this regard, restricting exchange rate to eliminate adverse effects of oil price shocks may thus be effective, nevertheless, may be supported with additional policies. 


\section{REFERENCES}

AJG Simoes, CA Hidalgo. (2011). The Economic Complexity Observatory: An Analytical Tool for Understanding the Dynamics of Economic Development. Workshops at the Twenty-Fifth AAAI Conference on Artificial Intelligence.

Aleisa, E. A., \& Dibooglu, S. (2002). Sources of Real Exchange Rate Movements in Saudi Arabia. Journal of Economics and Finance, 26(1), 101-110. https://doi.org/10.1007/BF02744455

Bermudez Delgado, N. A., Bermudez Delgado, E., \& Saucedo, E. (2018). The Relationship Between Oil prices, The Stock Market and The Exchange Rate: Evidence from Mexico. The North American Journal of Economics and Finance, 45, 266-275. https://doi.org/10.1016/j.najef.2018.03.006

Bernanke, S. B., Gertler, M., \& Watson, M. (1997). Systematic Monetary Policy and the Effects of Oil Price Shocks. Brookings Papers on Economic Activity,28(1), 91157.

http://doi.org/10.2307/2534702

Berument, M. H., Ceylan, N. B., \& Dogan, N. (2010). The Impact of Oil Price Shocks on the Economic Growth of the Selected MENA Countries. The Energy Journal, 31(1), 149-176. http://doi.org/10.5547/ISSN0195-6574-EJ-Vol31-No1-7

Cano, R., Gallardo, D., \& Acosta, J. (2019). Mexico: Free Floating Exchange Regime. In M. Chaman, D. Hofman \& N. E. Magud \& A. Werner (Eds.), Foreign Exchange Intervention in Inflation Targeters in Latin America (1th ed, 195-227). International Monetary Fund. http://dx.doi.org/10.5089/9781484375686.071

Carstens, A. G., \&Werner, A. (1999). Mexico's Monetary Policy Framework Under a Floating Exchange Rate Regime. Documentos De Investigación Del Banco De México, 13(2), 1-52.

https://www.imf.org/external/pubs/ft/seminar/2000/targets/carstens.pdf

Choi, S., Furceri, D., \& Loungani, P., \& Mishra, S., \& Poplawski-Ribeiro, M. (2018). Oil Prices and Inflation Dynamics: Evidence from Advanced and Developing Economies. Journal of International Money and Finance, 82, 71-96. https://doi.org/10.1016/j.jimonfin.2017.12.004.

Copelman, M., \& Werner, A. M. (1995). The Monetary Transmission Mechanism in Mexico. International Finance Discussion, 1-33. http://doi.org/10.17016/IFDP.1995.521 
Duclaud, J., \& Garcia, G. (2012). Mexico’s Oil Price- Hedging Program. In R. Arezki, C. Pattillo, M. Quintyn \& M. Zhu (Eds.), Commodity Price Volatility and Inclusive Growth in Low-Income Countries (pp.297-314). International Monetary Fund.

García, S., Saucedo, E., \& Velasco, A. (2018). The effects of oil prices on the spot exchange rate (mxn/usd) a var analysis for Mexico from 1991 to 2017. Análisis Económico, 33(84), 33-56.

Grigoli, F., Herman, A., \& Swiston, A. (2017). A Crude Shock: Explaining the Impact of the 2014-16 Oil Price Decline Across Exporters. IMF Working Papers, 17, 481-493. https://doi.org/10.1016/j.eneco.2018.11.025

Guerrero-Escobar S., Hernández-del-Valle G., \& Hernández-Vega M. A. (2018). Do heterogeneous countries respond differently to oil price shocks? Banco de México, 16, 1-29. https://doi.org/10.1016/j.jcomm.2018.12.001

IMF (2007), IMF Country Report: Mexico: 2007 Article IV Consultation Staff Report, IMF Publishing, Washington.

Jacyk, C. M. (1998). The Effects of Oil Price Shocks on Consumer Prices and Industrial Production in the United States, Canada and Mexico (Master's thesis, The University of Calgary, Alberta, Canada).

Jahan-Parvar, M. \& Mohammadi, H. (2008). Oil Prices and Real Exchange Rates in Oil-Exporting Countries: A Bounds Testing Approach. The Journal of Developing Areas, 45(1), 309-318. https://doi.org/10.1353/jda.2011.0020

Jiménez-Rodríguez, R., \& Sánchez, M. (2005). Oil Price Shocks and Real GDP Growth: Empirical Evidence for Some OECD Countries. Applied Economics, 37(2), 201-228. https://doi.org/10.1080/0003684042000281561

Kamin, S. B., \& Rogers, J. H. (2000). Output and the Real Exchange Rate in Developing Countries: An Application to Mexico. Journal of Development Economics, 61(1), 85-109. https://doi.org/10.1016/S0304-3878(99)00062-0

Lescaroux, F., \& Mignon, V. (2008). On the Influence of Oil Prices on Economic Activity and Other Macroeconomic and Financial Variables. OPEC Energy Review, 32(4), 343-380. https://doi.org/10.1111/j.1753-0237.2009.00157.x

Lizardo, R. A., \& Mollick, A. V. (2010). Oil price fluctuations and U.S. dollar exchange rates. Energy Economics, 32(2), 399-408. https://doi.org/10.1016/j.eneco.2009.10.005 
Mehrara, M., \& Mohaghegh, M. (2011). Macroeconomic Dynamics in the Oil Exporting Countries: A Panel VAR study. International Journal of Business and Social Science, 2(21), 288-295. https://doi.org/10.30845/ijbss

Mohammadi, H. \& Jahan-Parvar, M. (2010). Oil prices and exchange rates in oilexporting countries: Evidence from TAR and M-TAR models. Journal of Economics and Finance, 36(3), 766-779. https://doi.org/10.1007/s12197-0109156-5

OECD (2009), OECD Economic Surveys: Mexico 2009, OECD Publishing, Paris, https://doi.org/10.1787/eco_surveys-mex-2009-en.

Rogers, J. H., \& Wang, P. (1995). Output, Inflation, and Stabilization in a Small Open Economy: Evidence from Mexico. Journal of Development Economics, 46(2), 271-73. https://doi.org/10.1016/0304-3878(94)00064-J

Sek, S. K., Teo, X. Q. \& Wong, Y. N. (2015). A Comparative Study on the Effects of Oil Price Changes on Inflation. Procedia Economics and Finance, 26, 630-636. https://doi.org/10.1016/S2212-5671(15)00800-X

Sidaoui, J. J., (2005). Central Banking Intervention under a Floating Exchange Rate Regime: Ten Years of Mexican Experience. In J. J. Sidaoui(ed.), Foreign Exchange Market Intervention in Emerging Markets: Motives, Techniques and Implications (24, pp.209-30). Bank for International Settlements. http://www.bis.org/publ/bppdf/bispap24r.pdf

Skakun, Y. (2019). Transmission Mechanisms of Oil Price Shock and Its Effect on Output. In K. Beck (ed.), Resolving International Economic Problems with the Tools of Contemporary Econometrics (pp.166-202). Lazarski University Press, https://doi.org/10.26399/Beck2019-skakun

Truman, E. M. (1996). The Mexican Peso Crisis: Implications for International Finance. Federal Reserve Bulletin, 82(3), 1-11. https://www.federalreserve.gov/pubs/bulletin/1996/396lead.pdf

Volkov, N. I., \& Yuhn, K. (2016). Oil price shocks and exchange rate movements. Global Finance Journal, 31,18-30. https://doi.org/10.1016/j.gfj.2016.11.001 